\title{
Inventory and new records of benthic amphipods from macrophytes and fine sand communities of the Bizerte lagoon (Tunisia, SW Mediterranean Sea)
}

\author{
Marwa Khammassi ${ }^{1}$, Jérôme Jourde ${ }^{2^{*}}$ D, Wahiba Zaabar ${ }^{1}$, Sarra Laabidi ${ }^{1}$, Pierre-Guy Sauriau ${ }^{2}$ \\ and Mohamed Sghaier Achouri ${ }^{1}$
}

\begin{abstract}
Shallow water benthic communities from the Bizerte lagoon (northern Tunisia) were investigated at 33 stations sampled in April and July of 2016 and 2017. A total of 18 amphipod species were recorded among which two new species were recorded: one for Tunisian coasts (Jassa marmorata) and a second one for the Mediterranean Sea (Serejohyale spinidactylus). In addition, and compared to previous studies, nine amphipod species were collected for the first time in this lagoon. Amphipod assemblages were numerically dominated by the families Melitidae (28\%), Caprellidae (14.5\%) and Ampithoidae (11.7\%). Three species: Cymadusa filosa, Dexamine spinosa and Elasmopus rapax were numerically dominant. According to their biogeography, most of the recorded amphipod species (11-18) showed an Atlantic-Mediterranean distribution, whereas four were cosmopolitan and three lessepsian Indo-Pacific migrants, but no species were Mediterranean endemic. Specimens of both Jassa marmorata and Serejohyale spinidactylus are illustrated and described.
\end{abstract}

Keywords: Amphipoda, Serejohyale spinidactylus, Jassa marmorata, Diversity, Biogeography, Wetlands, Mediterranean

\section{Introduction}

The Order Amphipoda is a large group of crustaceans, shrimp-like in form, that inhabit various environments, mainly aquatic, from fully marine to fresh water including hypogean habitats (Sket 1999). In the marine realm, they represent one of the most important components of the macrozoobenthic communities in terms of diversity and abundance (Baldo et al. 2001). Thus, Mediterranean amphipod communities show a high species diversity with more than 452 recorded species (Ruffo 1998) inhabiting a large variety of habitats from coastal, including estuarine and brackish conditions, to the abyssal level. Amphipods reach a high level of diversity on plant substrata as seagrass and algae (Bellan-Santini 1999; Mc Cain 1968), and are often associated with other organisms such as bivalves, bryozoans, hydrozoans, and annelids. Furthermore, they

\footnotetext{
* Correspondence: jerome.jourde@univ-Ir.fr

2UMR 7266 LIENSs CNRS/La Rochelle Université, 2 rue Olympe de Gouges,

17000 La Rochelle, France

Full list of author information is available at the end of the article
}

play an important role in aquatic food webs by processing detritus, and constitute a link in the transfer of energy to higher trophic levels (Rogers et al. 2010).

The Bizerte lagoon is a shallow water Mediterranean ecosystem located in northeast Tunisia (Fig. 1). It plays a major hydrological transition role between the Mediterranean Sea and the Ichkeul Lake (Afli et al. 2008), known to be an important area of nursery and feeding grounds for marine, estuarine and freshwater species (Shaiek et al. 2015). Few studies have hitherto focused on the benthic communities of the Bizerte lagoon (e.g. Afli et al. 2009), and only scarce and fragmented data dealing with amphipods have been reported by Zaouali (1980) (three species) and Fezzani et al. (2001) (five species). More recently, new investigations on amphipod communities (Zaabar et al. 2015) reported the presence of 10 amphipod species at the Menzel Jemil station (St27) (Fig. 1).

The present study was implemented in order to contribute to the knowledge on Tunisian lagoon benthic 


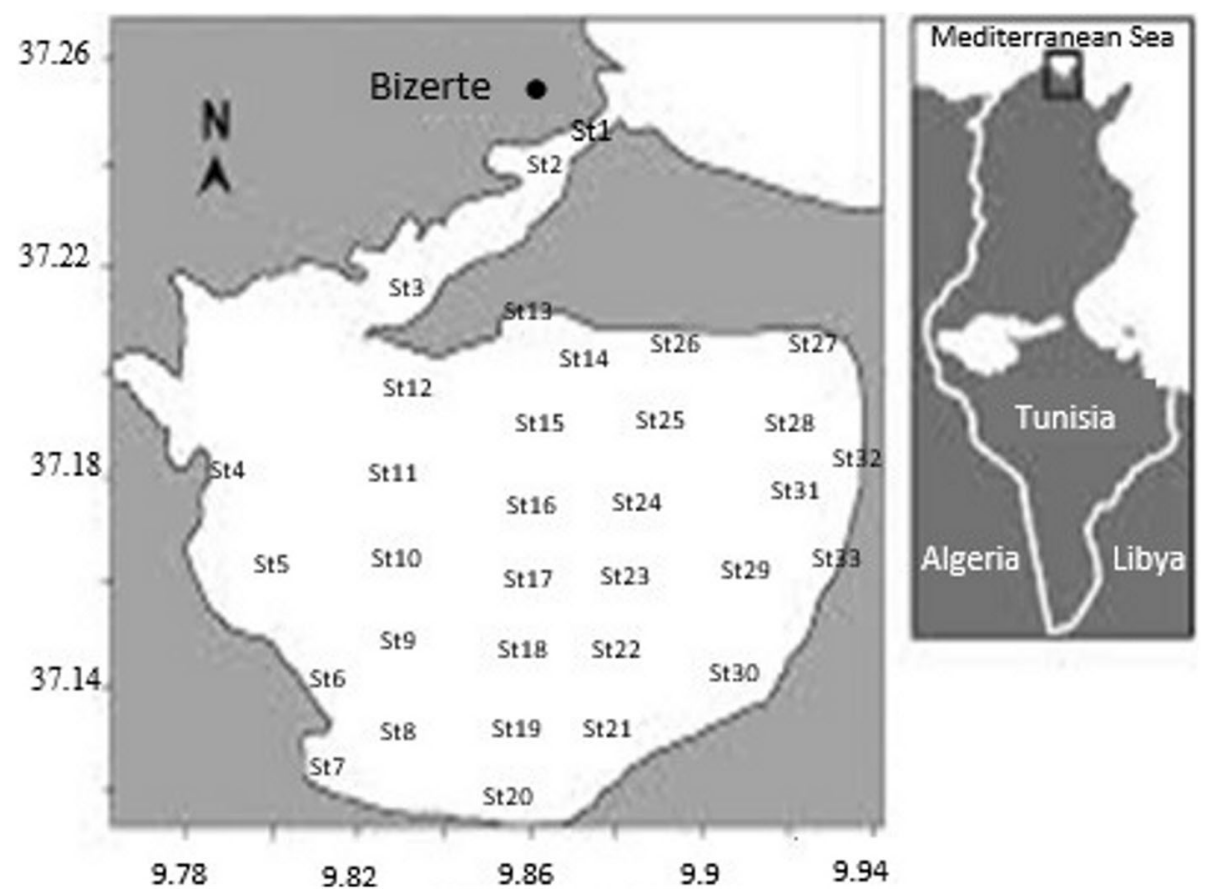

Fig. 1 Map of the Bizerte lagoon with location of sampling stations

macrofauna and focused on amphipod data collected from 33 stations in the Bizerte lagoon. Results are compared to previous amphipod inventories in order to highlight new records, autochthonous versus allochthonous status, and biogeographic affinities.

\section{Materials and methods}

\section{Study area}

The Bizerte lagoon, the third largest coastal lagoon in Tunisia, is located in northeast Tunisia $\left(37^{\circ} 08^{\prime}-37^{\circ} 17^{\prime}\right.$ $\mathrm{N} / 9^{\circ} 46^{\prime}-9^{\circ} 55^{\prime} \mathrm{E}$ ) (Fig. 1) and covers an area of $130 \mathrm{~km}^{2}$ with an average depth of $7 \mathrm{~m}$. This semi-enclosed ecosystem is connected with the Mediterranean Sea through the Navigation Channel $(6 \mathrm{~km}$ long, $7 \mathrm{~m}$ wide and $12 \mathrm{~m}$ deep), and with the Ichkeul Lake in the west through the Tinja Channel (ANPE 1990; Ouakad 2007). In addition, the lagoon receives freshwater input from 18 different non-permanent streams (Zmerli Triki et al. 2014). Sediments mainly consist of muddy sand, being covered in most areas with seagrass meadows of Cymodocea nodosa (Ucria) Ascherson, 1870 and Zostera noltei Hornemann, 1832, sciaphile algae Codium bursa (Olivi) C. Agardh, 1817 and the photophilic algae Dictyota dichotoma (Hudson) J.V. Lamouroux, 1809, Ellisolandia elongata (J.Ellis \& Solander) K.R. Hind \& G.W. Saunders, 2013, Padina pavonica (Linnaeus) Thivy in W.R. Taylor, 1960, Ulva lactuca Linnaeus, 1753, Cystoseira compressa (Esper) Gerloff \& Nizamuddin, 1975 and Gracilaria bursa-pastoris (S.G. Gmelin) P.C. Silva, 1952 (see
Djellouli 1988; Essid and Aissa 2002 for details). The lagoon has been exploited for fishing activities and shellfish farming of mussels Mytilus galloprovincialis Lamarck, 1819 and oysters Magallana gigas (Thunberg, 1793) for several decades (Beji 2000).

\section{Sampling}

Sampling was carried out at 33 stations (Fig. 1) in April and July during two consecutive years (2016 and 2017). At each station, three random replicates were placed between 0 and $11 \mathrm{~m}$ in macroalgae, seagrass meadows or sediment. Samples were collected using a metal quadrat of $25 \times 25 \mathrm{~cm}$ and a Van Veen grab $\left(400 \mathrm{~cm}^{2}\right)$ [see Additional file 1]. The collected macrophytes and sediment were washed and sieved through a $5-\mathrm{mm}$ and then a 1-mm mesh size sieve. The collected fauna was preserved in a 70\% ethanol-marine water solution. In the laboratory, amphipods were identified to species level and counted. Specimens were dissected using a stereomicroscope (LEICA MS5) and appendages were observed through a compound microscope (OLYMPUS BH-2). The identification of families, genera and species was performed using the identifications keys of Chevreux and Fage (1925) and Ruffo (1982, 1989, 1993, and 1998). However, Serejohyale spinidactylus (Chevreux, 1926) previously described by Chevreux (1926) as Hyale spinidactyla was identified following Serejo (2001) and Krapp-Schickel et al. (2011), whereas Caprella scaura 
Templeton, 1836 was identified using Krapp-Schickel et al. (2006).

\section{Nomenclature}

All the species were checked for the present valid nomenclature according to the World Amphipoda Database (Horton et al. 2019), which is part of the World Register of Marine Species (WoRMS Editorial Board 2019), except for the macroalgae species, for which a cross-validation of species names and authorities was based on AlgaeBase (Guiry and Guiry 2019).

\section{Data analyses}

The relative abundance (Ra), species richness and the mean density (individuals. $\mathrm{m}^{-2}$ ) were calculated for each station. Following Bellan-Santini and Ruffo (2003), the recorded species were classified in four potential geographical distribution groups: (A) species common to Mediterranean and Atlantic waters, (B) Lessepsian species, (C) Cosmopolitan and (D) endemic species.

\section{Results}

A total of 6058 amphipods belonging to 18 species, 16 genera and 12 families, were collected in the Bizerte lagoon during April and July of 2016 and 2017. Melitidae was the most species-rich family with 5 species. In terms of total abundance, the family Melitidae showed the highest value (1700 individuals, $28 \%$ ), followed by Caprellidae (882 individuals, 14.5\%) and Ampithoidae (708 individuals, 11.7\%). Eight species displayed relative abundance values higher than 5\% (Table 1): Cymadusa filosa Savigny, 1816 was the most abundant species (11.7\%), followed by Dexamine spinosa (Montagu, 1813) (11.1\%) and Elasmopus rapax Costa, 1853 (11\%) and they were largely distributed within the lagoon between $0.5-1,0.5-4$ and $0.5-10 \mathrm{~m}$ depth, respectively. The remaining species each contributed less than $5 \%$ of total abundance (Table 1) with Leucothoe incisa Robertson, 1892, Erichtonius difformis $\mathrm{H}$. Milne Edwards, 1830 and Lysianassa costae (H. Milne Edwards, 1830) as the less abundant species represented by < 300 individuals in total. The highest amphipod species richness was found at station 1 (14 spp.) and 26 (13 spp.), whereas the lowest value (one species) was observed at stations 10,15 and 25 . The highest population density detected was 4208 individuals/ $\mathrm{m}^{2}$, at station 27 in July 2016, whereas the lowest density was obtained at stations 9,10 , 11 and 12 in April 2016 (16 individuals $/ \mathrm{m}^{2}$ ), and no amphipod species were recorded at stations 16 and 17 .

Table 1 Amphipod species recorded in the Bizerte lagoon during the present study

\begin{tabular}{|c|c|c|c|c|}
\hline Family & Species & $\mathrm{Ra} \%$ & Habitat preference & $\mathrm{BG}$ \\
\hline Ampithoidae & Cymadusa filosa Savigny, 1816 & $11.7 \%$ & $\begin{array}{l}\text { Hard and sandy bottoms, among algae and } \\
\text { Cymodocea nodosa meadows }\end{array}$ & B \\
\hline Aoridae & Microdeutopus gryllotalpa Costa, 1853 & $10 \%$ & $\begin{array}{l}\text { Hard and sandy bottoms, among algae and } \\
\text { C. nodosa meadows }\end{array}$ & A \\
\hline \multirow[t]{2}{*}{ Caprellidae } & Caprella equilibra Say, 1818 & $5.9 \%$ & Among algae & C \\
\hline & Caprella scaura ${ }^{\text {a }}$ Templeton, 1836 & $8.6 \%$ & Among algae & B \\
\hline \multirow[t]{2}{*}{ Corophiidae } & Ericthonius difformis H. Milne Edwards, 1830 & $1.6 \%$ & Sandy bottom and among algae & A \\
\hline & Monocorophium insidiosum ${ }^{\mathrm{a}}$ (Crawford, 1937) & $8.6 \%$ & $\begin{array}{l}\text { Hard and sandy bottoms, Among algae and } \\
\text { C. nodosa meadows }\end{array}$ & C \\
\hline Dexaminidae & Dexamine spinosa (Montagu, 1813) & $11.1 \%$ & Hard bottom and among algae & A \\
\hline Gammaridae & Gammarus insensibilis Stock, 1966 & $2.6 \%$ & Among algae and $C$. nodosa meadows & A \\
\hline Hyalidae & Serejohyale spinidactylus ${ }^{\complement}$ (Chevreux, 1926) & $2.2 \%$ & Among algae and C. nodosa meadows & A \\
\hline Ischyroceridae & Jassa marmorata ${ }^{b}$ Holmes, 1905 & $4.4 \%$ & $\begin{array}{l}\text { Hard and sandy bottoms, among algae and } \\
\text { C. nodosa meadows }\end{array}$ & C \\
\hline Leucothoidae & Leucothoe incisa a Robertson, 1892 & $1.3 \%$ & Hard bottom and among algae & A \\
\hline Lysianassidae & Lysianassa costae (H. Milne-Edwards, 1830) & $1.4 \%$ & Among algae and C. nodosa meadows & A \\
\hline \multirow[t]{3}{*}{ Maeridae } & Elasmopus rapax (A. Costa in Hope, 1851) & $11 \%$ & $\begin{array}{l}\text { Hard and sandy bottoms, among algae and } \\
\text { C. nodosa meadows }\end{array}$ & C \\
\hline & Elasmopus pectenicrus ${ }^{\mathrm{a}}$ (Spence Bate, 1862) & $9.5 \%$ & Among algae and C. nodosa meadows & B \\
\hline & Quadrimaera inaequipes ${ }^{\mathrm{a}}$ (A. Costae in Hope, 1851) & $2.3 \%$ & Among algae & A \\
\hline Melitidae & Melita palmata (Montagu, 1804) & $2.4 \%$ & Among algae & A \\
\hline Nuuanuidae & Gammarella fucicola (Leach, 1814) & $2.9 \%$ & Among algae and C. nodosa meadows & A \\
\hline Talitridae & Orchestia mediterranea Costa, 1853 & $2.5 \%$ & Hard bottom & A \\
\hline
\end{tabular}

${ }^{a}$ new records in Bizerte lagoon, ${ }^{b}$ new records in Tunisia and ${ }^{~}$ new records in the Mediterranean Sea, (\%Ra) Relative abundance, (BG) Biogeography, A: species common to Mediterranean and Atlantic waters, B: Lessepsian species, C: Cosmopolitan species and D: Endemic species 
Nine species i.e. Caprella scaura Templeton, 1836, Elasmopus pectenicrus (Spence Bate, 1862), Jassa marmorata Holmes, 1905, Melita palmata (Montagu, 1804), Monocorophium insidiosum (Crawford, 1937), L. incisa, L. costae, Quadrimaera inaequipes (A. Costa in Hope, 1851) and Serejohyale spinidactylus have hitherto never been recorded from the Bizerte lagoon. In addition, J. marmorata and S. spinidactylus were reported for the first time in Tunisia. In addition, the latter is also newly reported for the Mediterranean Sea (Table 1). The classification of species in geographical distribution groups shows that most species have an Atlantic-Mediterranean distribution (group A: 11 species, 61\%), followed by cosmopolitan species (group C: 4 species, 22\%) and lessepsian species (group B: 3 species, 17\%). No endemic species (group D) were recorded (Table 1).

\section{Discussion}

The first marine amphipod inventory of the Tunisian coast was provided by Chevreux $(1910,1911)$, who recorded 65 species. Major updates to this inventory were made subsequently by Zakhama-Sraieb et al. (2009), Mosbahi et al. (2015) and Ounifi Ben Amor et al. (2016) focussing on introduced species. Combining the last available checklist of Zakhama-Sraieb et al. (2017) and recent records from Gulf of Gabès (Fersi et al. 2018) resulted in a total of 143 species belonging to 81 genera and 37 families for these coasts. However, amphipods of Tunisian lagoons such as the Tunis north, Bougrara, El Bibane and Bizerte lagoons have been sparsely studied (Fezzani et al. 2001; Diawara et al. 2008; Ben Souissi and Kahri 2010; Zaabar et al. 2015). Similarly to the sampling strategy utilised by Zaouali (1980), the present study investigated a large number (33) of stations in the Bizerte lagoon allowing 12 and 18 amphipod families and species to be recorded, respectively. The most frequent family was Melitidae with $28 \%$ of the total of species, followed by the Caprellidae $14.5 \%$ and the Ampithoidae $11.7 \%$. Out of the 18 species recorded in the present study, nine were reported for the first time in the lagoon: Caprella scaura, Elasmopus pectenicrus, Jassa marmorata, Leucothoe incisa, Lysianassa costae, Melita palmata, Monocorophium insidiosum, Quadrimaera inaequipes and Serejohyale spinidactylus. It should be also indicated that both $C$. scaura and $L$. incisa have been first recorded in the Bizerte lagoon in 2013 (Khammassi, unpub. data). However, except for S. spinidactylus, all amphipods from the Bizerte lagoon have already been recorded in several Mediterranean lagoons outside Tunisia (e.g. Diviacco and Bianchi 1987; Procaccini and Scipione 1992; Basset et al. 2006). Two species are noticeable since $J$. marmorata is reported for the first time in Tunisia (see Zakhama-Sraieb et al. 2017; Fersi et al. 2018), although S. spinidactylus is newly reported in both Tunisia and the Mediterranean Sea. As a result, this updates the list of marine Amphipoda in Tunisia estimated now to be 145 species, 83 genera and 37 families.

Amphipod specific richness observed herein considerably exceeds those previously mentioned in the Bizerte lagoon (Zaouali 1980; Fezzani et al. 2001) with three and five species, respectively. More recently, Zaabar et al. (2015) reported the presence of 10 species at the Menzel Jemil station (St27). The present amphipod species list is dominated by species having an Atlantic-Mediterranean distribution (12 species). Besides, three species are found to be lessepsian migrants (C. scaura, C. filosa and E. pectenicrus) out of the six lessepsian species known to be present on Tunisian coasts (Ounifi Ben Amor et al. 2016). The three other species i.e. Gammaropsis togoensis (Schellenberg, 1925), Hamimaera hamigera (Haswell, 1879) and Stenothoe gallensis Walker, 1904, were not recorded in the present study. Finally, four species, namely Caprella equilibra Say, 1818, E. rapax, J. marmorata and $M$. insidiosum are considered cosmopolitan species.

The three dominant species encountered in the Bizerte lagoon were C. filosa, D. spinosa and E. rapax. C. filosa prefers hard and sandy bottoms, Cymodocea nodosa meadows and photophilic algae (Cystoseira compressa, Gracilaria bursa-bastoris, Ellisolandia elongata and Caulerpa prolifera (Forsskål) J.V. Lamouroux, 1809 between 0.5 and $5 \mathrm{~m}$-depth. According to Hay et al. (1988, 1990) and Duffy and Hay (2000), these algal covers provide efficient shelter, as they are less palatable for larger herbivores such as fish that could consume the amphipods. D. spinosa was recorded on hard bottoms and photophilic algae (Bryopsis plumosa (Hudson) C. Agardh, 1823, Hypnea spp. J.V. Lamouroux, 1813 and Ellisolandia elongata) between 0.5 and $4 \mathrm{~m}$-depth, where it forms important communities. E. rapax, in agreement with the reports of Ruffo (1982), was collected in hard and sandy bottoms, between 0.5 and $10 \mathrm{~m}$-depth, often in Cymodocea nodosa meadows and photophilic algae i.e. Caulerpa prolifera, Dictyota dichotoma and Halopteris scoparia (Linnaeus, 1753). It is noteworthy that E. pectenicrus, a lessepsian species, co-occurred with its congeneric among algae and seagrass between 0.5 and 5 m-depth.

\section{Mediterranean and Tunisian new records - systematic and ecological considerations Order AMPHIPODA Latreille, 1816. \\ Family HYALIDAE Bulycheva, 1957. Genus Serejohyale Bousfield \& Hendryckx, 2002. Serejohyale spinidactylus (Chevreux, 1926).}

(Figs. 2 and 3)

The main diagnostic features allowing identification of the Serejohyale specimens are given by Arresti (1996) 

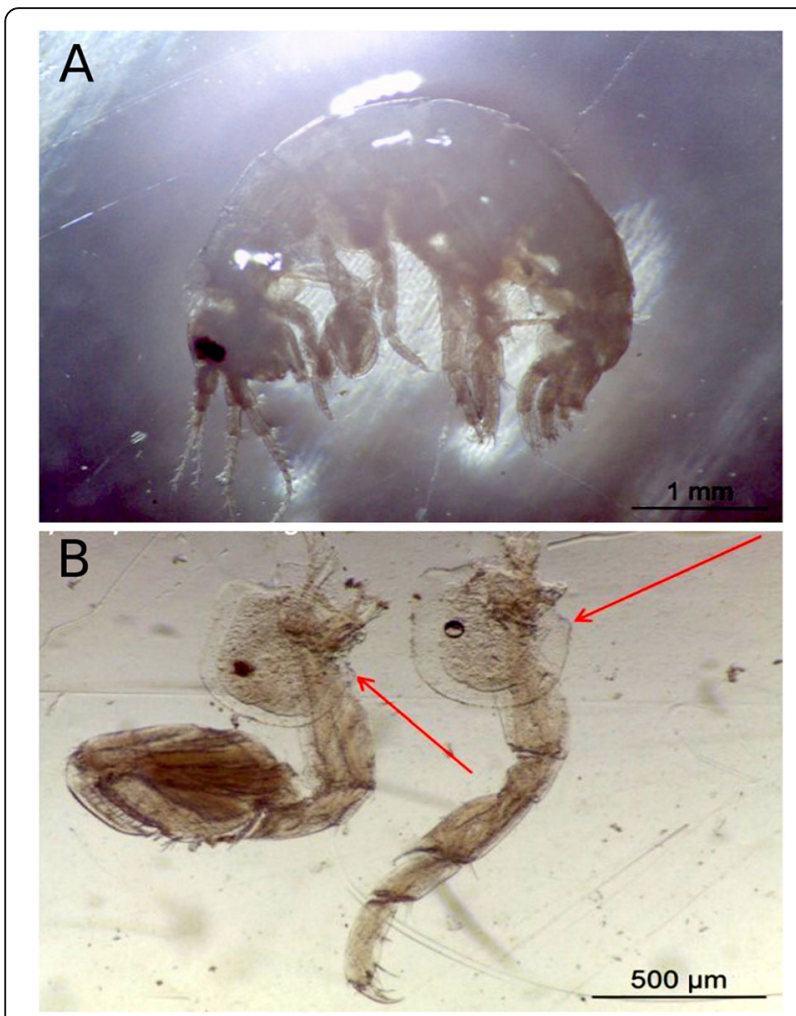

Fig. 2 Serejohyale spinidactylus from the Bizerte lagoon, a male, entire animal, lateral view, b male, Gn2 and P3: cusp on posterior margin of coxa (arrows)

and Serejo (2001). S. spinidactylus is characterised by its great seta on the dactylus of the pereopods $3-7$, the lack of setae on the posterior margin of the pereopods $6-7$, the two well developed disto-lateral spines on the peduncle of the uropod 1 and the presence of four spines on the peduncle of uropod 2. No Mediterranean Hyalidae species shares this combination of features.

\section{Material examined}

Based on 10 adult males, body length (BL): $5 \mathrm{~mm}-8.4$ $\mathrm{mm}$; 10 adult females, BL: 4,1 mm-7,7 mm; 10 Juveniles, BL: 2,0-3,4 mm; Bizerte lagoon (north Tunisia): stations 1, 2, 26 and 27 (Fig. 1), July 2017, 1-3 m deep.

\section{Description}

Male

Head with large and oval eyes (Fig. 2a). Antenna 1 reaching about $1 / 4$ of body length; flagellum with 12 articles. Antenna 2 reaching about $1 / 3$ of body length; flagellum with 16 articles. Epistome triangular, upper lip large with many short apical spines. Mandible without palp; molar process powerful; lacinia mobilis with a single row of 11-12; maxilla 1 inner lobe with two feathered apical spines, outer lobe as long as the inner lobe and defined by nine spines strongly serrated; maxilla 2
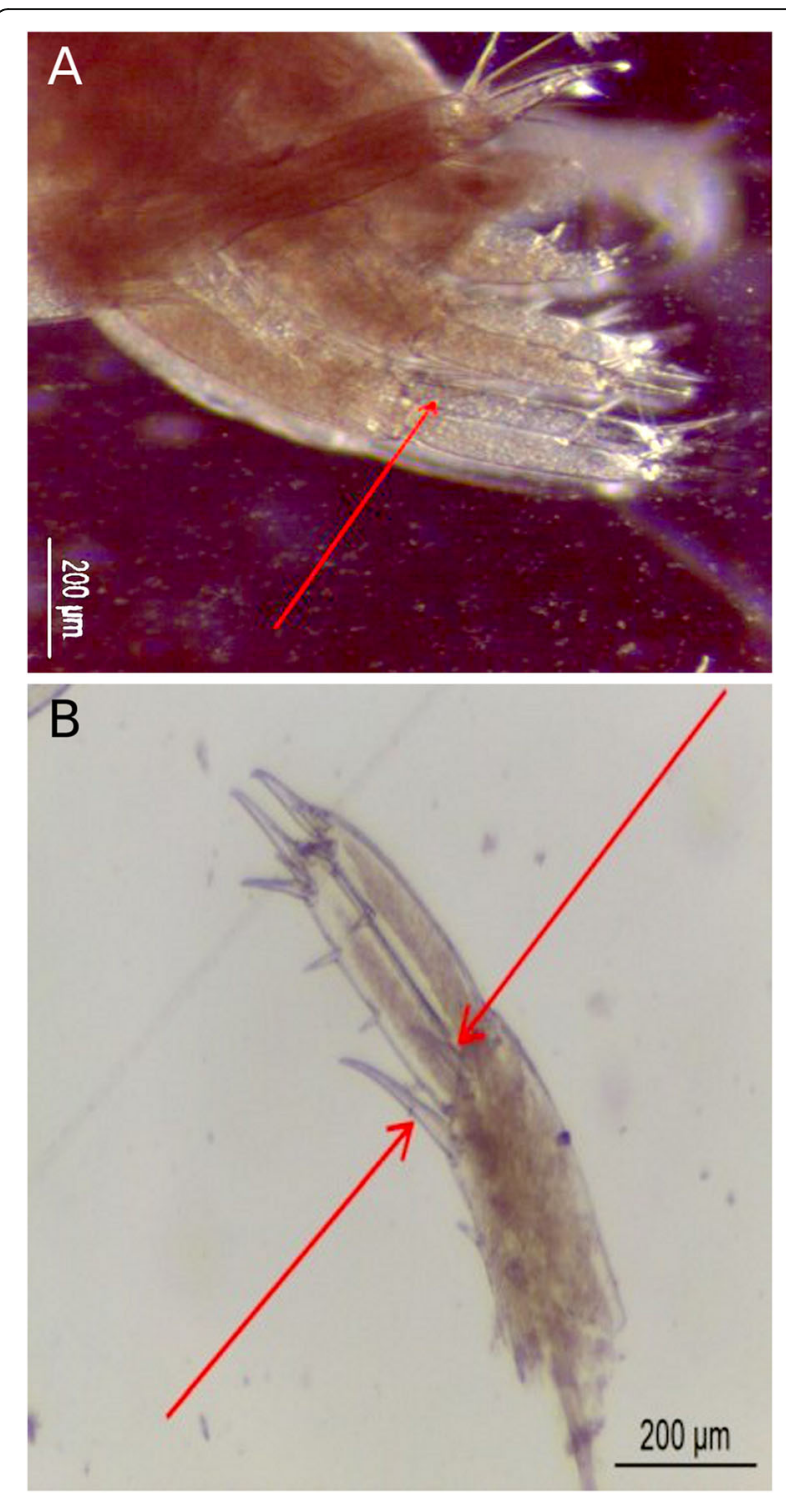

Fig. 3 Serejohyale spinidactylus from the Bizerte lagoon, a uropod, b U1, distolateral and distomedial spines of peduncle (arrows)

inner lobe with seven dentate spines, several simple setae, and two plumose setae; maxilliped palps robust, maxilliped inner lobe reaching the second article of the palp, defined by three apical teeth and a few setae.

Gnathopods 1-2 distinctly different in size. Gnathopod 1 basis robust; carpus large and rounded with 19 setae; propodus posterior margin with a median group of setae, palm slightly oblique, with two spines; dactylus fitting palm. Gnathopod 2 basis large; ischium short and lobed, anterior margin defined by a short triangular carpal lobe with distal spine; propodus palm posterior margin with a small concavity and a distal process, defined by few spines and setae; dactylus fitting palm. Gnathopod 2 and pereopod 3 coxae with cusp on posterior margin (Fig. 2b). Coxae 1-4 with posterior processes 
slightly reduced. Pereopods 3-4 propodus with four spines sub-equal in length. Pereopods 5-7 basis expanded, propodus with three groups of spines followed by one spine surrounded by setae and a distal spine larger than the others, inserted near dactylus articulation. Pereopod 5 propodus posterior margin with two medial setae. Pereopods 6-7 propodus posterior margin with few setae medially.

Epimera 2-3 postero-ventral margin slightly sinuous.

Uropod 1 peduncle robust, slightly longer than rami, with five spines on outer margin, two spines on inner margin, and two well-developed disto-lateral spines (Fig. 3a, b); rami slightly larger than peduncle, defined by three marginal spines. Uropod 2 shorter than uropod 1 ; peduncle robust with eight spines on outer margin and one spine on inner margin; rami with four marginal spines and two apical spines. Uropod 3 peduncle with two distal spines, one spine less than $1 / 5$ length of the other; rami with eight distal spines. Telson triangular lobes separated from base.

\section{Female}

Antenna 1 slightly longer than male antenna 1, defined by 10 articles with fewer setae. Antenna 2 slightly longer than antenna 1 , defined by fewer setae; flagellum with 14 articles. Gnathopod 2 carpus well developed, palm oblique with several long setae and two large spines. Second oostegite triangular; oostegites 3-4 rectangular; oostegite 5 sub-triangular and smaller than former ones.

\section{Variations}

A morphological dimorphism between the juvenile and adult male was observed. The shape of the palm of gnathopod 2 in juvenile males varies during the stage of development. In juveniles, the palm is oblique, with the carpal lobe well developed. In larger specimens, the carpal lobe disappears, but the palm is still oblique. In adults, the palm is large, and extends over the entire propodus, with the defining spines in a more proximal position. The propodus also varies in juveniles, it is twice as long as it is wide, and the anterior margin lacks setae.

In addition, specimens collected in the Bizerte lagoon differ slightly from Serejo's re-description (2001) as they show a slenderer and not striated robust seta on P3 dactylus.

\section{Habitat}

Juveniles and adults occupy brown algae such as Dictyopteris polypodioides (A.P. de Candolle, 1805), Dictyota dichotoma and Sargassum vulgare (C.Agardh, 1820) between 2 and $6 \mathrm{~m}$ depth.

\section{Geographical distribution}

Considered as an Atlantic endemic species, S. spinidactylus has been first described from the Canary Islands (Chevreux 1925). The species has been subsequently recorded from S o Tomé Island, Cape Verde, Azores, coast of the Basque Country and northern Spain (Serejo 2001) among algae as Ellisolandia elongata, Jania rubens (J.V. Lamouroux, 1816), Ulva rigida (J. Agardh, 1883) and Chaetomorpha sp. (Krapp-Schickel et al. 2011). In Tunisia, the species may have been formerly overlooked. Its arrival pathway to the Bizerte lagoon remains unclear but international maritime shipping, through hull fouling and/or ballast waters, is the most likely. The port of Bizerte is located on a strategic position along the SuezGibraltar maritime axis, and generates an average traffic of goods of about 5 million tons per year (OMMP 2016). Actually, although the species was recorded in the north eastern part of the lagoon, $80 \%$ of the individuals (49 out of 61) were collected in the transitional channel, in the vicinity of the port of Bizerte. Then, the water circulation scheme within the Bizerte lagoon can explain the presence of some individuals (12 specimens) in the northern sector of the lagoon where marine influence is predominant (Harzallah 2003; Béjaoui et al. 2008; Béjaoui 2009).

\section{Order AMPHIPODA Latreille, 1816.}

\section{Family ISCHYROCERIDAE Stebbing, 1899. \\ Genus Jassa Leach, 1814. \\ Jassa marmorata Holmes, 1905.}

The main diagnostic features allowing identification of the Jassa specimens are given by Conlan (1990).

\section{Material examined}

Based on 10 adult males, BL: $6-8 \mathrm{~mm}, 10$ adult females, BL: $4.8-6 \mathrm{~mm}, 10$ Juvenile $(2 \mathrm{~mm})$; Bizerte lagoon ( $\mathrm{N}$ Tunisia), stations 14 and 31 near shellfish farming (Fig. 1), July, 2017, 2-4 m deep.

\section{Description \\ Males}

Head with rounded lateral cephalic lobe; eyes round, moderately large. Antenna 1 robust, reaching about one fifth of body length, article 3 almost as long as article 2; flagellum short, equal to peduncular article 3 , with up to 7 articles; accessory flagellum minute. Antenna 2 larger and stouter than antenna 1 (Fig. 4a); flagellum shorter than peduncular article 5, with up to 4 articles, posterior margin with long simple setae proximally and short plumose setae distally. Mandibular palp segments 2-3 without dorsal fringe of setae; Maxilla 1 palp segment 1 without setae at base, segment 2 with one row of facial setae.

Gnathopod 1 basis with few short setae along anterior and posterior margins and at the distal angle; propodus 

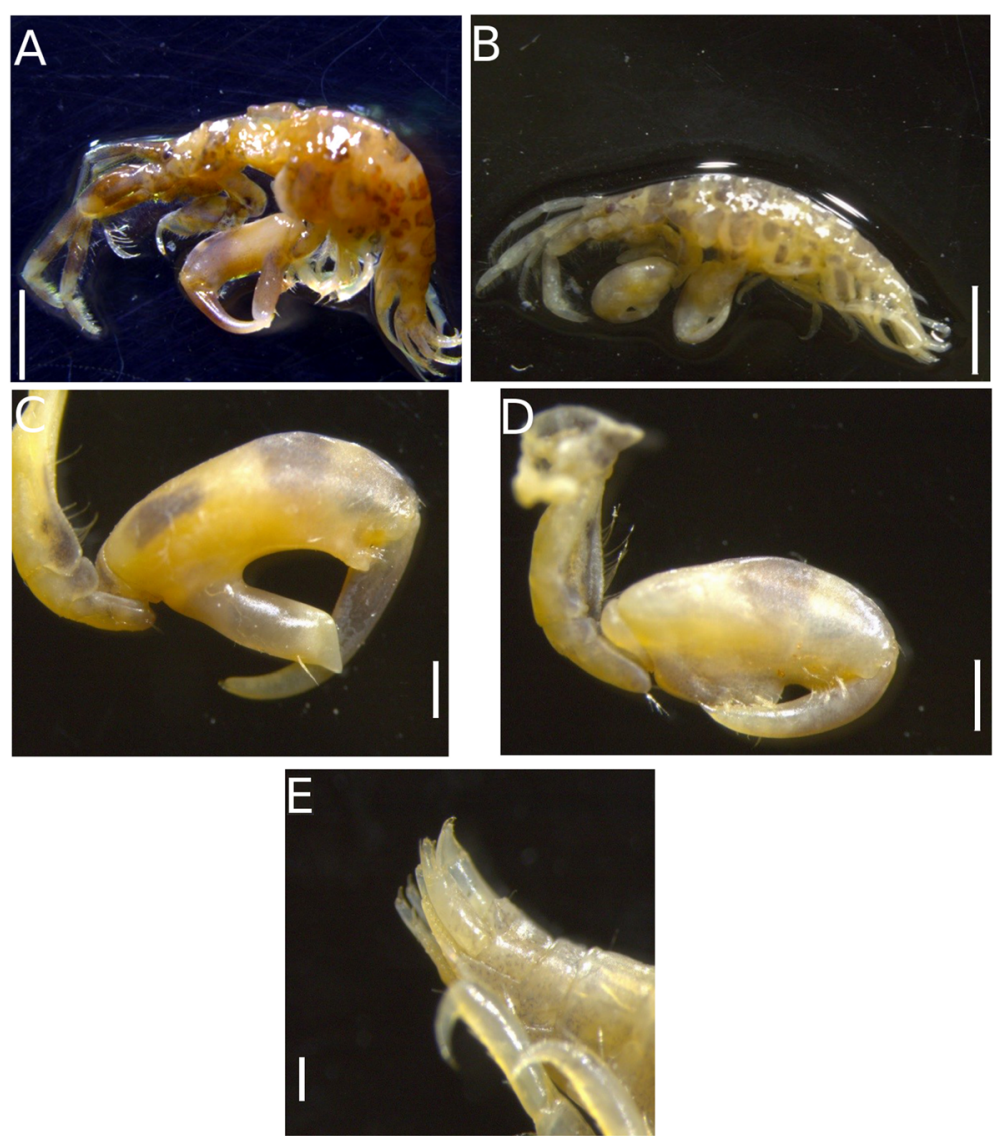

Fig. 4 Jassa marmorata from the Bizerte lagoon, a male, b female, c Gn2 male, $\mathbf{d}$ Gn2 female, e telson male (scales $\mathbf{a}, \mathbf{b} 2 \mathrm{~mm} ; \mathbf{c}, \mathbf{d} 500 \mu \mathrm{m}$; e $200 \mu \mathrm{m})$

oval with a strongly oblique palm defined by $2-3$ small spines; dactylus stout, fitting palm. Coxa 2 short and angular with posterior angle elongated, becoming triangular in hyperadults. Gnathopod 2 basis stout; carpus very reduced, posterior lobe with $1 \mathrm{~min}$ distal seta; propodus massive with proximal and pointed tooth, anterior margin with short setae proximally, thumb reaching about $1 / 3$ of propodus length, distally squared, posterior margin slightly indented at thumb setae and slightly expanded at location of defining setae; dactylus inner margin broadly expanded at location of hinge tooth (Fig. 4c). Coxa 3 stout, greatest depth posterior to the centre. Pereopod 3 basis anterior margin slightly convex; merus long anterior marginal setae clustered proximally and covering full length; carpus fully overlapped by merus. Pereopods 6-7 robust; basis posterodistal margin produced into a lobe; dactylus without fringe of setae along anterior margin.

Uropod 1-2 outer rami slightly shorter than inner rami. Uropod 1 peduncle with posteroventral spinous process underlying the third of inner ramus; inner and outer rami with 5 and 6 mid-dorsal spines, respectively. Uropod 2 peduncle posteroventral spinous process underlying the fifth of inner ramus. Uropod 3 inner ramus straight, outer ramus with hooked apical spine and several denticles (23). Telson subtriangular (Fig. 4e).

\section{Females}

(sexually dimorphic characters based on female with oostegites): Antenna 2 peduncle article 5 with filter setae somewhat shorter and sparser than in males. Coxa 1-2 ventral margin linear. Gnathopod 2 larger than gnathopod 1 (Fig. 4b); basis inner margin serrate, provided with long setae; propodus large and oval with single excavation, hinge tooth pronounced, palmar setae relatively dense, palmar angle acute, distal, and close to defining spines; dactylus inner margin straight, tip fitting into a depression between the palmar angle and defining spines (Fig. 4d).

Specimens, males and females, show distinct brownish and yellowish markings throughout (Fig. 4a, b).

\section{Variations}

Body size at maturity: males are $4.0-7.1 \mathrm{~mm}$ and females $3.2-6.2 \mathrm{~mm}$. The brush setae on antenna 2 and the setae on the basis of pereopods 3 and 4 increase in abundance with body size. The long simple setae on flagellum 
article 3-5 shortens a little as the male grows. In juveniles, the gnathopod 2 propodus has a triangular indentation posterior to the reduced palm.

\section{Remarks}

Following Conlan (1990), J. marmorata can be most easily mistaken for J. staudei Conlan 1990. Specimens of $J$. marmorata are characterised by shorter setae on the anterior margin of the propodus of gnathopod 2, and by possessing a short, slightly lateral seta at the anterodistal junction of the carpus and propodus of gnathopod 1. In addition, J. marmorata does not reach great body size as $J$. staudei does. The high polymorphism in Jassa, mainly linked to the particular reproductive pattern in this genus (Beermann and Purz 2013), results in a marked sexual dimorphism that is easily detectable. Thus, males of $J$. marmorata present two sexually mature morphs: large males are twice as big as females and small males and present an enlarged thumb on gnathopod 2, while a much smaller thumb located closer to the dactylus is present in small males. Moreover, body size is an excellent predictor of morph type in J. marmorata, mature males being bigger (body length at maturity $6.9-8.8 \mathrm{~mm}$ ) than small males $(2.4-3.1 \mathrm{~mm})$ and females $(4.8-7.1$ $\mathrm{mm})$. Actually, most of the collected specimens were juveniles (56.2\%) and females (34.2\%), the remaining were a few large males $(9.6 \%)$. The preponderance of juveniles in the summer samples should correspond with an order-of-magnitude increase in the number of females early in the summer, as stated by Clark (1997) for small males.

\section{Habitat}

Juveniles and adults were collected among green and red algae, associated with Cymodocea nodosa meadow and on hard bottoms with Hypnea spp., and Caulerpa prolifera at 2-4 $\mathrm{m}$ depth. According to Conlan (1990), the species can also be recorded from mussels, hydroid, bryozoan, tube worm colonies and Ulva spp.

\section{Geographical distribution}

Native of North Atlantic America and the Gulf of Mexico, the species has a worldwide putative distribution: East Pacific (Canada, USA, Mexico, Chile), West Pacific (the Sea of Japan, Australia, New Zealand), the North East Atlantic Ocean, the South Atlantic Ocean (Africa and South America), and the Mediterranean Sea (Pilgrim and Darling 2010).

In this study, J. marmorata is reported with large numbers from two stations located at $10-15 \mathrm{~m}$ depth, within the vicinity of shellfish farming activities located on the northeastern part of the Bizerte lagoon (Beji 2000; Zaabar et al., 2017). Since species of this genus do not have planktonic larval dispersal phase (Conlan 1989) and can therefore hardly colonise remote environments by migration, shellfish farming activities remain the most likely introduction pathway. Actually, with a production of Mytilus galloprovincialis (Lamarck, 1819) reaching 130 tons per year, the Bizerte lagoon is one of the main mussel aquaculture areas in Tunisia. Moreover, a fouling arrival linked to shipping (see Nunes et al. 2014 for a review) is unlikely since the commercial port of Bizerte is located $20-30 \mathrm{~km}$ from the studied area, and this species was not collected in the transition channel connecting the lagoon with the Mediterranean Sea.

\section{Additional information}

The amphipods of the genus Jassa Leach, 1814 include approximately 36 species (Horton et al. 2019). Despite the great ecological importance of Jassa species, little is known about species-specific biological and ecological traits (Beermann and Purz 2013). This mainly results from a former systematic confusion in Jassa spp. due to the high phenotypic polymorphism in the genus. Prior to Conlan's major revisions $(1989,1990)$, all individuals of the genus Jassa were considered as Jassa falcata (Montagu, 1808) as stated by Sexton and Reid (1951). Therefore, all ecological studies on Jassa published before 1990 have to be challenged, because they possibly dealt with a mixture of species (Beermann and Purz 2013).

\section{Conclusion}

New records of Serejohyale spinidactylus and Jassa marmorata increase amphipod species inventory in Tunisian marine waters, and also contribute to update the Mediterranean Sea amphipod checklist. However, amphipod species richness known from the Tunisian coasts remains lower than those observed from neighbouring coasts i.e. the Algerian, Libyan, Italian and French Mediterranean coasts (see the reviews by Dauvin and BellanSantini 2002; Ruffo 2010; Mosbahi et al. 2015). Despite a much lower coastal length compared to these countries, it raises the need to increase the sampling effort along Tunisian coasts (Mosbahi et al. 2015) and particularly within lagoon ecosystems, as promoted by the present study. This will help to better describe biodiversity of amphipod fauna and characterise its functional potentialities. In view of the unprecedented rate of marine alien invasions within the Mediterranean Sea (Galil 2000; Nunes et al. 2014), and the intermediate biogeographical location of Tunisian coasts between the Alboran Sea (connected to the Atlantic ocean) and the Oriental part of the Mediterranean Sea (particularly vulnerable to Lessepsian migrants), this will also help to better evaluate potential ecological risks due to new incoming species, and identify possible threats in a context of both global warming and increasing commercial exchanges by aquaculture and shipping. 


\section{Supplementary information}

Supplementary information accompanies this paper at https://doi.org/10. 1186/s41200-019-0182-5.

Additional file 1. Description of the sampling stations in the Bizerte lagoon (depths, coordinates, habitats) and sampling methods used in the present study.

\section{Acknowledgments}

The authors wish to thank the team of the Biodiversity and Functioning Laboratory of Aquatic Systems (BFSA), University of Carthage, for their help in collecting samples. The authors also thank Alan Myers for his kindness and advice. MK thanks the LIENSs laboratory for supplying lab facilities during a one-month stage in June 2017 at La Rochelle. The authors are grateful to the two anonymous reviewers for their detailed and very helpful comments, and to Proofreading Service UK Communications LTD for proofreading and editing the manuscript.

\section{Authors' contributions}

MSA and MK are project leaders of the study. MK, MSA and SL were involved in field work. MK and JJ identified the specimens and made figures. All authors were involved in the setup of the manuscript, led by MK in collaboration with WK, JJ and PGS. All authors read and approved the final manuscript.

\section{Funding}

This study is part of a PhD thesis funded by the Diversity, Management and Conservation of Biological Systems Laboratory, LR18ES06, Faculty of Sciences of Tunis, University of Tunis El Manar.

\section{Availability of data and materials}

The datasets generated during and/or analyzed during the current study are not publicly available since the thesis is not yet completed and results not entirely published. Data are available in part from the corresponding author on reasonable request.

\section{Ethics approval and consent to participate}

Not applicable.

\section{Competing interests}

The authors declare that they have no competing interests.

\section{Author details}

'Diversité, gestion et conservation des systèmes biologiques, LR18ES06, Faculté des Sciences de Tunis, Université de Tunis El Manar, 2092 Manar II, Tunis, Tunisia. ${ }^{2}$ UMR 7266 LIENSs CNRS/La Rochelle Université, 2 rue Olympe de Gouges, 17000 La Rochelle, France.

\section{Received: 21 March 2019 Accepted: 14 November 2019}

\section{Published online: 21 December 2019}

\section{References}

Afli A, Ayari R, Zaabi S. Ecological quality of some Tunisian coast and lagoon locations, by using benthic community parameters and biotic indices. Estuar Coast Shelf Sci. 2008;(2):269-80. https://doi.org/10.1016/j.ecss.2008.08.010.

Afli A, Boufahja F, Sadraoui S, Ben Mustapha K, Aïssa P, Mrabet R. Functional organization of the benthic macrofauna in the Bizerte lagoon (SW Mediterranean Sea), semi-enclosed area subject to strong environmental/ anthropogenic variations. Cah Biol Mar. 2009;50(2):105. https://doi.org/10. 21411/CBM.A.1504FA90.

ANPE. Etude préliminaire de l'écologie du lac de Bizerte. Rapport, Agence Nationale de Protection de l'Environnement, Tunis; 1990.

Arresti A. Descripción del anfípodo marino Hyale spinidactya Chevreux, 1926 (Crustacea, Amphipoda, Gammaridea) en el País Vasco. Misc Zool. 1996;19: 79-91.

Baldo F, Arias AM, Drake P. The macrobenthic community of the Guadalquivir estuary. Bol Inst Esp Oceanogr. 2001;17:137-48.

Basset A, Galuppo N, Sabetta L. Environmental heterogeneity and benthic macroinvertebrate guilds in Italian lagoons. Transit Water Bull. 2006;1(1):48. https://doi.org/10.1285/i1825226Xv1n1p48.
Beermann J, Purz AK. Comparison of life history parameters in coexisting species of the genus Jassa (Amphipoda, Ischyroceridae). J Crustac Biol. 2013;33(6): 784. https://doi.org/10.1163/1937240X-00002190.

Béjaoui B. Développement d'un modèle tridimensionnel couplé dynamique-écologie : application à la lagune de Bizerte. In: Rapport de thèse de spécialité en génie hydraulique. Tunis: ENIT, Département d'hydraulique; 2009

Béjaoui B, Harzallah A, Moussa M, Chapelle A, Solidoro C. Analysis of hydrobiological pattern in the Bizerte lagoon (Tunisia). Estuar Coast Shelf Sci. 2008:80(1):121. https://doi.org/10.1016/j.ecss.2008.07.011.

Beji O. Les ressources vivantes exploitables du lac de Bizerte: Etat actuel et potentialités (première partie). Bull Inst Natn Scien Tech Mer de Salammbô. 2000;27:45-60.

Bellan-Santini D. Ordre des Amphipodes (Amphipoda Latreille, 1816). In: Forest J, editor. Traité de Zoologie, Anatomie, Systématique, Biologie, vol. 19. Monaco: Tome VII, Fascicule III A. Crustacés Péracarides. Mem Inst Oceanogr; 1999. p. 93-176.

Bellan-Santini D, Ruffo S. Biogeography of benthic marine amphipods in Mediterranean Sea. Biogeographia. 2003:24:273-91.

Ben Souissi J, Kahri C. Ben Les espèces non indigènes du macrobenthos des lagunes du sud-est tunisien : point sur la situation. Rapp Comm int Mer Médit. 2010;39:449.

Chevreux E. Note sur les Crustacés Amphipodes d'Algérie et de Tunisie. Bull Soc Hist Nat Afrique N. 1910;2:135-7.

Chevreux E. Campagnes de la Melita : Les Amphipodes d'Algérie et de Tunisie. Mem Soc Zool France. 1911;23:145-285.

Chevreux E. Voyage de la goélette Melita aux Canaries et au Sénégal 1889-1890. Amphipodes. I. Gammariens (suite). Bull Soc Zool Fr. 1925:50:365-93.

Chevreux E, Fage L. Faune de France: Amphipodes. Paris : Office Central de Faunistique de la Fédération Française des Sociétés de Sciences Naturelles; 1925.

Conlan KE. Delayed reproduction and adult dimorphism in males of the amphipod genus Jassa (Corophioidea: Ischyroceridae): an explanation for systematic confusion. J Crustac Biol. 1989;9(4):601. https://doi.org/10.2307/ 1548592.

Conlan KE. Revision of the crustacean amphipod genus Jassa leach (Corophioidea: Ischyroceridae). Can J Zool. 1990;68(10):2031. https://doi.org/ 10.1139/z90-288.

Dauvin JC, Bellan-Santini D. Benthic amphipoda gammaridea from the French coast: a review of current knowledge. Crustaceana. 2002;75:299-340.

Diawara M, Tlig-Zouari S, Rabaoui L, Ben Hassine OK. Impact of management on the diversity of macrobenthic communities in Tunis north lagoon: systematics. Cah Biol Mar. 2008;(1):49, 1. https://doi.org/10.21411/CBM.A. 194C9208.

Diviacco G, Bianchi CN. Faunal interrelationships between lagoonal and marine amphipod crustacean communities of the Po River Delta (northern Adriatic). An Biol (Biologia Ambiental). 1987:12:67-77.

Djellouli A. Recherche sur le macro phytobenthos de la lagune de Bizerte (Tunisie). Diplôme d'Etudes Approfondies, Faculté des sciences de Tunis; 1988.

Duffy JE, Hay ME. Strong impacts of grazing amphipods on the organization of a benthic community. Ecol Monogr. 2000;70(2):237. https://doi.org/10.2307/2657176.

Essid N, Aissa P. Etude quantitative des nématodes libres des secteurs Nord et Est de la lagune de Bizerte (Tunisie). Bull Inst Natn Scien Tech Mer de Salammbô. 2002:29:53-63.

Fersi A, Dauvin J, Pezy JP, Neifar L. Amphipods from tidal channels of the Gulf of Gabès (central Mediterranean Sea). Mediterr Mar Sci. 2018;19(3):430. https:// doi.org/10.12681/mms.15913.

Fezzani S, Zghal F, Ben Amor Z, El Abed A. Etude systématique et écologique de la faune associée aux moules (Mytilus galloprovincialis). Bull Inst Natn ScienTech Mer de Salammbô. 2001;28:89-97.

Galil BS. A sea under siege-alien species in the Mediterranean. Biol Invasions. 2000;2(2):177. https://doi.org/10.1023/A:1010057010476.

Guiry M.D., Guiry G.M. AlgaeBase. World-wide electronic publication, National University of Ireland, Galway. 2019; http://www.algaebase.org; searched on 23 July 2019.

Harzallah A. Transport des polluants dans la lagune de Bizerte simulé par un modèle de circulation de l'eau. Bull Inst Natn Scien Tech Mer de Salammbô. 2003:30:115-33.

Hay ME, Duffy JE, Fenical W. Host-plant specialization decreases predation on a marine amphipod: an herbivore in plant's clothing. Ecology. 1990;71(2):733. https://doi.org/10.2307/1940326 
Hay ME, Duffy JE, Fenical W, Gustafson K. Chemical defense in the seaweed Dictyopteris delicatula: differential effects against reef fishes and amphipods. Mar Ecol Prog Ser. 1988;48:185-92.

Horton T, Lowry J, De Broyer C, Bellan-Santini D, Coleman CO, Corbari L, Costello MJ, Daneliya M, Dauvin J-C, Fišer C, Gasca R, Grabowski M, Guerra-García JM, Hendrycks E, Hughes L, Jaume D, Jazdzewski K, Kim Y-H, King R, KrappSchickel T, LeCroy S, Lörz A-N, Mamos T, Senna AR, Serejo C, Sket B, SouzaFilho JF, Tandberg AH, Thomas JD, Thurston M, Vader W, Väinölä R, Vonk R, White K, Zeidler W. World Amphipoda Database; 2019. World Amphipoda database. Accessed at http://www.marinespecies.org/amphipoda on 201907-24. https://doi.org/10.14284/368.

Krapp-Schickel T, Guerra-Garcia JM, Baeza-rojano E, Cabezas MP. Taxonomy and ecology of some gammaridean species (Crustacea: Amphipoda) from Tarifa Island, southern Spain. J Mar Biol Assoc UK. 2011;91(2):447. https://doi.org/10. 1017/S0025315410000810.

Krapp-Schickel T, Lang C, Libertini A, Melzer RR. Caprella scaura Templeton, 1836 sensu lato (Amphipoda: Caprellidae) in the Mediterranean. Org Divers Evol. 2006;6(2):77. https://doi.org/10.1016/j.ode.2005.04.004.

Mc Cain JC. The Caprellidae (Crustacea: Amphipoda) of the Western North Atlantic. Bull. U.S. Natl. Mus. Washington D.C: Smithsonian Institution Press; 1968.

Mosbahi N, Dauvin JC, Neifar L. First record of the amphipods Leucothoe incisa (Robertson, 1892) and Lysianassa pilicornis (Heller, 1866) from Tunisian waters (Central Mediterranean Sea). Vie et Milieu - Life and Environment. 2015;65: 175-9.

Nunes AL, Katsanevakis S, Zenetos A, Cardoso AC. Gateways to alien invasions in the European seas. Aquat Invasions. 2014;9(2):133. https://doi.org/10.3391/ai. 2014.9.2.02.

OMMP. Office de la Marine Marchande et des Ports, Republic of Tunisia, Ministry of Transport. (2016). http://www.ommp.nat.tn/bizerte-menzel-bourguiba-en/ ?lang=en. Accessed 22 Aug 2019.

Ouakad M. Genèse et évolution des milieux laguno-lacustres du Nord-Est de la Tunisie (Garaet el Ichkeul, Lagunes de Bizerte et Ghar el Melh). Thesis. Tunis: Univ. el Manar; 2007.

Ounifi Ben Amor K, Rifi M, Ghanem R, Draief I, Zaouali J, Ben Souissi J. Update of alien fauna and new record from Tunisian marine waters. Mediterr Mar Sci. 2016;17(1):124. https://doi.org/10.12681/mms.1371.

Pilgrim EM, Darling JA. Genetic diversity in two introduced biofouling amphipods (Ampithoe valida \& Jassa marmorata) along the Pacific north American coast: investigation into molecular identification and cryptic diversity. Divers Distrib. 2010;16(5):827. https://doi.org/10.1111/j.1472-4642.2010.00681.x.

Procaccini G, Scipione MB. Observations on the spatio-temporal distribution of crustacean amphipods in the Fusaro coastal lagoon (Central Tyrrhenian Sea, Italy) and some notes on their presence in Mediterranean lagoons. Mar Ecol. 1992;13(3):203. https://doi.org/10.1111/j.1439-0485.1992.tb00351.x.

Rogers DC, Covich AP, Thorp JH. Chapter 18-Introduction to the subphylum Crustacea. In: Thorp JH, Covich AP, editors. Ecology and classification of North American freshwater invertebrates. 3rd ed. San Diego: Academic Press (Elsevier); 2010

Ruffo S. The Amphipoda of Mediterranean. Part 1: Gammaridea (Acanthonotozomatidae to Gammaridae). Monaco: Musée Océanographique: Mémoire de I'Institut Océanographique de Monaco 13; 1982.

Ruffo S. The Amphipoda of the Mediterranean. Part 2. Gammaridea (Haustoridae to Lysianassidae). Monaco, 13. Monaco: Musée Océanographique: Mémoires de l'Institut Océanographique; 1989.

Ruffo S. The Amphipoda of the Mediterranean. Part 3. Gammaridea (Melphidipiidae to Talitridae) - Ingolfiellidea - Caprellidea. Monaco, 13. Monaco : Musée Océanographique: Mémoires de l'Institut Océanographique; 1993.

Ruffo S. The Amphipoda of Mediterranean. Part 4: localities and map-agenda to parts 1-3-key to families_ecology_faunistics and zoogeography. Mémoire de l'Institut Océanographique de Monaco 13. Musée Océanographique: Monaco; 1998.

Ruffo S. Amphipoda. Biol Mar Mediterr. 2010;17(Suppl 1):499-515.

Serejo CS. A new species of amphipod from the Brazilian coast, with redescription of Hyale spinidactyla Chevreux 1925 (Crustacea, Amphipoda, Hyalidae). Zoosystema. 2001;23:479-92.

Sexton EW, Reid DM. The life-history of the multiform species Jassa falcato (Montagu) (Crustacea Amphipoda) with a review of the bibliography of the species. Zool J Linnean Soc. 1951. https://doi.org/10.1111/j.1096-3642.1951. tb01852.x.
Shaiek M, Romdhane MS, Le Loc'h F. Study of the ichthyofauna diet in the Ichkeul Lake (Tunisia). Cybium. 2015. https://doi.org/10.26028/cybium/2015393-003.

Sket $\mathrm{B}$. The nature of biodiversity in hypogean water and how it is endangered. Biodivers Conserv. 1999. https://doi.org/10.1023/A:1008916601121.

WoRMS Editorial Board. World Register of Marine Species; 2019. Available from http://www.marinespecies.org at VLIZ. ; Accessed 2019-07-23. https://doi.org/ 10.14284/170.

Zaabar W, Zakhama-Sraieb R, Charfi-Cheikhrouha F, Sghaïer Achouri M. Abundance and diversity of amphipods (Crustacea: Peracarida) on shallow algae and seagrass in lagoonal ecosystem of the Mediterranean Tunisian coast. Zool Stud. 2015. https://doi.org/10.1186/s40555-015-0113-z.

Zakhama-Sraieb R, Mnasser I, Zribi I, Charfi-Cheikhrouha F. Update of checklist of marine Amphipoda in Tunisia from 2009 to April 2017. Biodiv J. 2017:8:493-6.

Zakhama-Sraieb R, Sghaier YR, Charfi-Cheikhrouha F. Amphipod biodiversity of the Tunisian coasts: update and distributional ecology. Mar Biodivers Rec. 2009. https://doi.org/10.1017/S1755267209990820.

Zaouali J. Flore et faune benthiques de deux lagunes tunisiennes : le lac de Bizerte (Tunisie septentrionale) et la mer de Bougrara (Tunisie méridionale). Bull Off Natn Pêch Tunisie. 1980;4:196-200.

Zmerli Triki H, Kefi Daly-Yahia O, Malouche D, Komiha Y, Deidun A, Brahim M, Laabir M. Distribution of resting cysts of the potentially toxic dinoflagellate Alexandrium pseudogonyaulax in recently-deposited sediment within Bizerte Lagoon (Mediterranean coast, Tunisia). Mar Pollut Bull. 2014. https://doi.org/ 10.1016/j.marpolbul.2014.05.014.

\section{Publisher's Note}

Springer Nature remains neutral with regard to jurisdictional claims in published maps and institutional affiliations.
Ready to submit your research? Choose BMC and benefit from:

- fast, convenient online submission

- thorough peer review by experienced researchers in your field

- rapid publication on acceptance

- support for research data, including large and complex data types

- gold Open Access which fosters wider collaboration and increased citations

- maximum visibility for your research: over $100 \mathrm{M}$ website views per year

At BMC, research is always in progress.

Learn more biomedcentral.com/submissions 